\title{
Aluminium toxicity in winter wheat
}

\author{
A. Szabó-Nagy \\ e-mail: szna@mk.u-szeged.hu
}

\author{
E. Gyimes \\ A. Véha \\ e-mail: gyimes@mk.u-szeged.hu \\ e-mail: veha@mk.u-szeged.hu \\ University of Szeged, Faculty of Engineering, \\ Department of Food Engineering, \\ Moszkvai Sq. 5-7, 6725 Szeged, Hungary
}

\begin{abstract}
Aluminium is the most frequent metal of the earth crust; it occurs mainly as biologically inactive, insoluble deposit. Environmental problems, industrial contaminations and acid rains increase the soil acidity, leading to the mobilization of Al. Half of the world's potential arable lands are acidic; therefore, Al-toxicity decreases crop productivity. Wheat is a staple food for $35 \%$ of the world population. The effects of Al-stress $(0.1 \mathrm{mM})$ were studied on winter wheat; seedlings were grown hydroponically, at acidic pH. After two weeks, the root weight was decreased; a significant difference was found in the P- and Ca-content. The shoot weight and element content changed slightly; Al-content in the root was one magnitude higher than in the shoot, while Al-translocation was limited. The root plasma membrane $\mathrm{H}^{+}$-ATPase has central role in the uptake processes; Al-stress increased the $\mathrm{Mg}^{2+}$-ATPase activity of the microsomal fraction.
\end{abstract}

\section{Introduction}

Aluminum is a light metal, ubiquitous throughout the environment; it occurs mainly as insoluble deposit, which form is biologically inactive. Environmental factors increase the acidity of the soils, leading to the mobilization of the

Keywords and phrases: aluminium stress, plasma membrane $\mathrm{H}^{+}$-ATPase, phosphorus, Tricitum aestivum. 
bound form of Al. Food packaging and post-use disposal cause environmental pollution; recently, aluminium foils are priority toxins in the United States and Germany. $\mathrm{Al}$ is generally harmless to plant growth in $\mathrm{pH}$-neutral soils, but in acid soils the concentration of toxic $\mathrm{Al}^{3+}$ cations increases (Bedö et al., 1992; Bóna \& Carver, 1992; Zsoldos et al., 1998; Yang et al., 2013.). Approximately over $50 \%$ of the world's potential arable lands are acidic; therefore, $\mathrm{Al}$ toxicity is a major factor reducing plant growth and limiting crop productivity. The trivalent $\mathrm{Al}^{3+}$ ion is toxic to all living cells (Driscoll, 1985). In humans, $\mathrm{Al}^{3+}$ ion may cause a variety of neurological disorders and it has a significant role in Alzheimer's disease (AD). In plants, ionic $\mathrm{Al}$ rapidly inhibits root elongation and subsequently the uptake of nutrients and water (Ligaba et al., 2004.), resulting in poor growth. Al toxicity is a major limiting factor of crop production on acid soils (Kochian et al., 2004). Some plants have evolved mechanisms to detoxify $\mathrm{Al}^{3+}$, both externally and internally ( $\mathrm{Ma}$ \& Furukawa, 2003).

In higher plants, the Al-induced secretion of organic acid (OA) from the roots and the role of phosphorus (binding to the aluminium) is a known mechanism of Al tolerance ( $M a$ et al., 2001). The Al-induced secretion of OA anions may be related to several factors, including anion channels, transporters and the root plasma membrane (PM) $\mathrm{H}^{+}$-ATPase. In spite of the accumulated data, little is known about the avoidance of the toxic effects caused by aluminium stress on plants and about the changes in physiological and enzymatic properties of the root plasma membrane.

In this study, the in vivo effect of soluble $\mathrm{Al}^{3+}$ form on winter wheat was followed for two weeks. The changes caused by Al-stress in the growth and in some important element content were measured. Root microsomal fractions enriched in PM were prepared from the Al-treated and the control plants, and the $\mathrm{Mg}^{2+}$ ATPase activity of the fractions was compared.

\section{Materials and Methods}

\section{Plant growth and element analysis}

A nutrient solution (modified Hoagland) at $\mathrm{pH}=4.5$ containing $0.1 \mathrm{mM} \mathrm{AlCl} 3$ was used to examine the effect of $\mathrm{Al}$ on wheat (Triticum aestivum L. cv. Martonvásári-8). Control plants were grown under Al-free condition and Pdeficient plants were grown without phosphorus. Fifty seeds were then placed on plastic nets over plastic beakers, each containing $4 \mathrm{dm}^{3}$ of nutrient solution, and 4 replicate beakers were cultivated in the case of each treatment. 
The seedlings were grown hydroponically under controlled condition for two weeks with a 12 -h day-time illumination of $60 \mathrm{~W} \cdot \mathrm{m}^{-2}$; day/night temperatures were $23 / 18^{\circ} \mathrm{C}$ and the relative humidity of the air was $85 \%$. The fresh and the dry weight of the root and shoot were measured, and N, P, K, Ca and $\mathrm{Al}$ content were determined after wet digestion. Nitrogen content was analysed with the Kjedahl method, phosphorus was determined colorimetrically and the content of $\mathrm{K}, \mathrm{Ca}$ and $\mathrm{Al}$ was measured by atomic absorption spectrophotometry described by Szabó-Nagy et al., 1987.

\section{Isolation of plasma membrane vesicles and enzyme assay}

Young roots were harvested, washed in cold distilled water and homogenized in $3 \times$ volumes of homogenization buffer containing $250 \mathrm{mM}$ sucrose, $5 \mathrm{mM}$ EDTA and $50 \mathrm{mM}$ Tris-MES buffer (pH 7.5). The 10,000-30,000 g microsomal fraction was prepared and $\mathrm{Mg}^{2+}$-ATPase activity was measured as described earlier (Szabó-Nagy et al. 1987, 1992). Background ATPase activity was measured in the presence of $0.1 \mathrm{mM}$ EDTA, $0.1 \mathrm{mM}\left(\mathrm{NH}_{4}\right)_{6} \mathrm{Mo}_{7} \mathrm{O}_{24}, 1 \mathrm{mM}$ $\mathrm{NaN}_{3}, 3 \mathrm{mM}$ ATP, $25 \mathrm{mM}$ Tris-MES buffer ( $\mathrm{pH}$ 6.0) with $0.015 \mathrm{mg}$ proteincontaining fraction.

The fresh and the dry weight of the root and shoot were measured as averages of 5 plants. The element concentrations were given as the mean of three replicate determination; replicates differed by less than 10\%. Microsomal ATPase activities were determined for three independent series of plants, and they gave similar results.

\section{Statistical analysis}

For statistical analysis, the ANOVA method was used.

\section{Results and discussion}

In this study, the in vivo effects of the ionic form of $\mathrm{Al}(0.1 \mathrm{mM}$, at $\mathrm{pH}$ 4.5) on wheat growth and on the element contents were followed (Table 1); control plants were grown under $\mathrm{Al}$ free condition. The weight of the roots was decreased ( $82 \%$ of the control) by $\mathrm{Al}$ stress, but in the case of the shoots no significant changes were found after two weeks. The decreased root growth could be a consequence of the Al-induced inhibition of the root elongation. The $\mathrm{Al}$ content of the roots was nearly one magnitude higher than that of the 
shoots in the Al-treated plants, suggesting that the translocation of $\mathrm{Al}$ was hindered.

No significant differences were found in the potassium and nitrogen content of the control and Al-treated plants: it varied between 95 and $104 \%$ as regards the control, both in the case of the roots and the shoots. In the $\mathrm{P}$ and $\mathrm{Ca}$ content of the roots, significant differences were found caused by $0.1 \mathrm{mM} \mathrm{Al}$ addition to the nutrient solution. The $\mathrm{P}$ content was increased by $35 \%$ and the Ca content was decreased by $26 \%$. The precipitation of aluminium by phosphorus in the apoplast and the accumulation of Al-P complex in the root can explain the measured increased $\mathrm{P}$ level. The Al-induced inhibition of $\mathrm{Ca}^{2+}$ uptake was found by Huang et al. (1992) in the Al-sensitive wheat. Changes in ionic composition of wheat root indicate that the ionic uptake processes were affected by Al-stress.

Table 1: Comparison of the growth and some important element content of the control and Al-treated wheat plants. Similar results were obtained in three independent series of plants

\begin{tabular}{lc}
\hline & $\begin{array}{c}\text { Changes caused by Al treatment } \\
\text { as \% of the control plants }\end{array}$ \\
\hline weight of roots & $82 \% \pm 5 \%$ \\
weight of shoots & $98 \% \pm 6 \%$ \\
P content of roots & $135 \% \pm 5 \%$ \\
P content of shoots & $108 \% \pm 7 \%$ \\
Ca content of roots & $74 \% \pm 7 \%$ \\
Ca content of shoots & $102 \% \pm 4 \%$ \\
& Al content, umol/g dry weight \\
in the roots & $79 \pm 5$ \\
in the shoots & $8 \pm 2$ \\
\hline
\end{tabular}

The root plasma membrane $\mathrm{H}^{+}$ATPase plays a central role in the ionic uptake processes. The microsomal fractions enriched in PM vesicles were prepared from the roots and the $\mathrm{Mg}^{2+}$-ATPase activity was measured in the case of Al-treated and control plants (Figure 1). In vivo Al stress caused an increase of the $\mathrm{Mg}^{2+}$-ATPase activity in the microsomal fraction: the $\mathrm{Mg}^{2+}$ ATPase activity was more than two times higher in the case of Al-treated plants than 
that of the control. The Al-induced changes may be related to different factors, such as phosphorus metabolism, as it was suggested by increased $\mathrm{P}$ content and the increased $\mathrm{Mg}^{2+}$-ATPase enzyme activity. Similarly, increased $\mathrm{Mg}^{2+}$-ATPase enzyme activity was observed in P-deficient plants, where the measured increase connected to an increased acid phosphatase activity (SzabóNagy et al., 1987).

The microsomal fraction may contain other enzymes attached to the vesicles, for example acid phosphatases from cytoplasm or from cell wall. Acid phosphatases are widely distributed in plants. These enzymes have intraand extracellular activity, and their roles are very important in phosphorus metabolism: they increase the amount of the available inorganic phosphate or they play a role in signal transduction. However, acid phosphatase activity is increased by other stress factors, for example by salt and osmotic stress (Szabó-Nagy et al., 1992; Szabó-Nagy \& Erdei, 1995; Ehsanpour \& Amini, 2013).

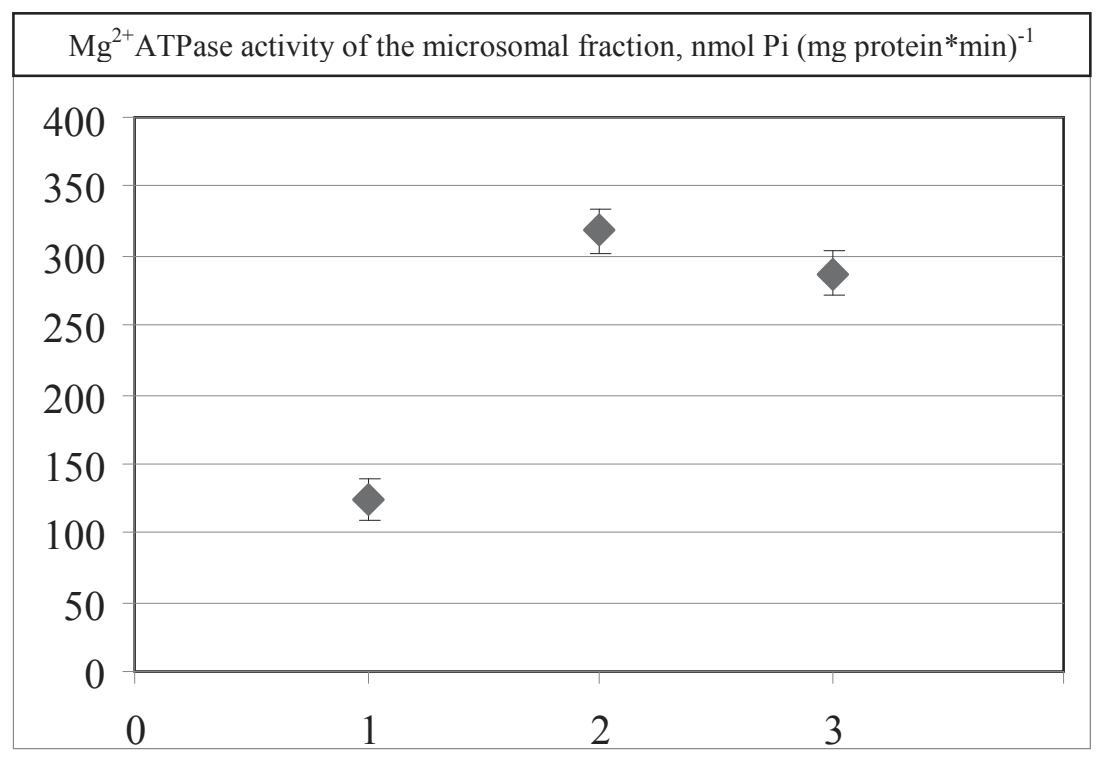

Figure 1: In vivo effect of Aluminium stress (2) and P deficiency (3) on the $\mathrm{Mg}^{2+}$ ATPase activity of the microsomal fraction in 14-day-old plants grown hydroponically with or without $0.1 \mathrm{mM} \mathrm{AlCl}_{3}$ in the nutrient solution. 1 stands for the control. 
Al-induced reduction in growth can be the result of a depletion of organic $\mathrm{P}$ pool in the plants. On the contrary, higher concentrations will just be the result of impaired growth. Effects of $\mathrm{Al}$ stress and $\mathrm{P}$ deficiency on nutrient uptake, proton efflux and root respiration were similar (Keltjens \& Loenen, 1990). Suppressed ionic $\left(\mathrm{Ca}^{2+}\right)$ net uptake might be the result of the enhanced leakage of plasma membranes due to a shortage of phospholipids as induced by deficient $\mathrm{P}$ supply or the malfunctioning of $\mathrm{Al}$-saturated phospholipids in the presence of $\mathrm{Al}^{3+}$. Reduced root respiration and deteriorated root energy supply might also disturb the nutrient uptake. Aluminum (Al) toxicity and phosphorus (P) deficiency often coexist in acid soils and severely limit crop growth and production. $\mathrm{P}$ addition significantly increased $\mathrm{Al}$ tolerance in four soybean genotypes differing in $\mathrm{P}$ efficiency. Some genotypes may be able to enhance $\mathrm{Al}$ tolerance not only through direct $\mathrm{Al}-\mathrm{P}$ interactions but also through indirect interactions (Liao et al., 2006). Low P availability is another important limiting factor to plant growth in acid soils. Generally, Al toxicity and $\mathrm{P}$ deficiency are studied separately as independent factors. Al toxicity and $\mathrm{P}$ deficiency often coexist in acid soils, and these two factors may strongly interact through chemical and biochemical reactions. It is necessary to think of the interactions between $\mathrm{Al}$ and other factors in the soil, particularly the $\mathrm{P}$ status.

$\mathrm{P}$ deficiency and $\mathrm{Al}$ stress have some similar effects on plants, for example significantly reduced root weight. However, the interaction of $\mathrm{Al}$ and the metabolism of other important elements, such as $\mathrm{P}$, needs more studies. A general mechanism of $\mathrm{Al}$ tolerance in plants is the release of organic acid anions from the roots in response to $\mathrm{Al}$ stress (Kochian et al., 2005); these anions chelate $\mathrm{Al}$ and form non-phytotoxic $\mathrm{Al}$ forms $(M a, 2007)$. Xia et al. (2013) found the gene of a plasma membrane-localized transporter for $\mathrm{Al}$ in rice. The changes caused by $\mathrm{Al}$ stress in transporters and in root plasma membrane $\mathrm{H}^{+}$-ATPase need further studies.

\section{Conclusion}

The aluminium stress is a very serious and growing problem, strengthening crop production in the last decades since the acidity of the soil is increasing. Some plant species and cultivars have evolved some mechanisms for detoxifying Al both internally and externally. There is some evidence that aluminium detoxification and phosphorus metabolism have some connections. The $\mathrm{Al}$ stress caused retardation of root growth parallel to the increased $\mathrm{Al}$ and in- 
creased P content. Against the increased P level, there could be a shortage of the accessible phosphorus. This increased $\mathrm{P}$ level could be the part of the strategy against $\mathrm{Al}$ stress since the insoluble Al-P complexes could reduce the toxic form of aluminium. The available $\mathrm{P}$ level could be decreased, leading to $\mathrm{P}$ deficiency symptoms. The decreased $\mathrm{Ca}^{2+}$ content of the roots could be the result of the changes of the ionic uptake processes caused by $\mathrm{Al}$ stress. ATPase activity of the root microsomal fraction, enriched in PM, was increased in Al-stressed 14-day-old plants, which increase was similar to that of the roots grown under $\mathrm{P}$ deficiency. The increase in the microsomal $\mathrm{Mg}^{2+}$ ATPase activity due to $\mathrm{Al}$ stress needs further studies, since the measured increase could be originated from acid phosphatase induction, as it was found in $\mathrm{P}$ deficient wheat roots.

\section{Acknowledgement}

This study was supported by TÁMOP-4.1.1.C-12/1/KONV-2012-0014 Project.

\section{References}

[1] Z. Bedő, I. Karsai, Gy. Vida, Bezosztaja 1 és Mironovszkaja 808 származékok csíranövénykori aluminium-toleranciája. Növénytermelés, 41. (1992) 393-400.

[2] L. Bóna, B. F. Carver, Őszi búza (Triticum aestivum L.) genotípusok csíranövénykori alumínium toxicitással szembeni toleranciája. Növénytermelés, 41. (1992) 381-391.

[3] C. T. Driscoll, Aluminum in acidic surface waters. Chemistry, transport, and effects. Environ. Health Perspect, 63. (1985) 93-104.

[4] A. Ehsanpour, F. Amini, Effect of salt and drought stress on acid phosphatase activities in alfalfa (Medicago sativa L.) explants under in vitro culture. African Journal of Biology, 1. 2. (2013) 120-121.

[5] L. Erdei, A. Szabó-Nagy, M. Laszlavik, Effects of tannin and phenolics on the $\mathrm{H}^{+}$-ATPase activity in plant plasma membrane. J. Plant Physiol., 144. (1994) 49. 
[6] J. W. Huang, J. E. Shaff, D. L. Grunes, L. V. Kochian, Aluminum effects on calcium fluxes at the root apex of aluminum-tolerant and aluminumsensitive wheat cultivars. Plant Physiology, 98. 1. (1992) 230-237.

[7] W. G. Keltjens, E. Loenen, Similarities and differences between aluminium toxicity and phosphorus deficiency in sorghum (Sorghum bicolor) plants. Developments in Plant and Soil Sciences, 41. (1990) 403-407.

[8] L. V. Kochian, O. A. Hoekenga, M. A. Pineros, How do crop plants tolerate acid soils? Mechanisms of aluminium tolerance and phosphorus efficiency. Annual Review of Plant Biology, 55. (2004) 459-493.

[9] L. V. Kochian, M. A. Pineros, O. A. Hoekeng, The physiology, genetics and molecular biology of plant aluminum resistance and toxicity. Plant Soil, 274. (2005) 175-195.

[10] H. Liao, H. Wan, J. Shaff, X. Wang, X. Yan, L. V. Kochian, Phosphorus and aluminum interactions in soybean in relation to aluminum tolerance. Exudation of specific organic acids from different regions of the intact root system. Plant Physiology, 141. 2. (2006) 674-684.

[11] A. Ligaba, H. Shen, K. Shibata, Y. Yamamoto, S. Tanakamaru, H. Matsumoto, The role of phosphorus in aluminium-induced citrate and malate exudation from rape (Brassica napus), Physiologia Plantarum, 120. 4. (2004) 575-584.

[12] J. F. Ma, P. R. Ryan, E. Delhaize, Aluminium tolerance in plants and the complexing role of organic acids. Trends in Plant Science, 6. (2001) $273-278$.

[13] J. F. Ma, J. Furukawa, Recent progress in the research of external Al detoxification in higher plants: a minireview. J. Inorg Biochem., 97. 1. (2003) 46-51.

[14] J. F. Ma, Syndrome of aluminum toxicity and diversity of aluminum resistance in higher plants. Int. Rev. Cytol., 264. (2007) 225-252.

[15] A. Szabó-Nagy, Z. Oláh, L. Erdei, Phosphatase induction in roots of winter wheat during adaptation to phosphorus deficiency. Physiologia Plantarum, 70. (1987) 544-552. 
[16] A. Szabó-Nagy, A. G. Galbiba, L. Erdei, Induction of soluble phosphatases under ionic and non-ionic osmotic stress in wheat. J. Plant Physiol., 140. (1992) 629-633.

[17] A. Szabó-Nagy, L. Erdei, Phosphatase induction under stress conditions in wheat. In: F. Baluska (ed.), Structure and Function of Roots, (1995) $163-167$.

[18] J. Xia, N. Yamaji, T. Kasai, J. F. Ma, Plasma membrane-localized transporter for aluminum in rice. Proceedings of the National Academy of Sciences, 107. 43. (2013) 18381-18385.

[19] L. T. Yang, Y. P. Qi, H. X. Jiang, L. S. Chen, Roles of organic acid anion secretion in aluminium tolerance of higher plants. BioMed Research International, (2013) 16.

[20] F. Zsoldos, Á. Vashegyi, A. Pécsváradi, L. Bóna, Zs. Szegletes, Alumínium- és nitritstressz hatása közönséges őszi búza és durum búza csíranövénykori növekedésére és káliumtranszportjára. Növénytermelés, 47, (1998) 491-502. 